\title{
The European Citizens' Initiative in Times of Brexit
}

\author{
Natassa Athanasiadou*
}

\section{I \\ Introduction}

The European citizens' Initiative is an instrument of participatory democracy $^{1}$ introduced by the Lisbon Treaty (Art.11(4) TEU ) and aiming to reinforce the influence of citizens over the legislative agenda of the EU. ${ }^{2}$ Pursuant to Art. 11(4) TEU, not less than one million citizens who are nationals of a significant number of Member States may take the initiative of inviting the European Commission, within the framework of its powers, to submit any appropriate proposal for a legal act of the Union. The right to participate in a European citizens' initiative constitutes one of the specific forms of the general right of every EU citizen to participate in the democratic life of the Union (Art. 1O(3) TEU ). ${ }^{3}$ It enables the involvement of EU citizens in the decision-making process at the EU level, while requiring that they come together with citizens from other Member States and present a proposal not of national, but of European interest. It thus introduces a new dimension of transnational participatory democracy, alongside representative democracy on which the EU is founded, ${ }^{4}$ and adds another tool to the political arsenal of EU citizenship. ${ }^{5}$

* Assistant Professor of EU Law, Maastricht University.

1 On participatory democracy and the scope of Art. 11 TEU, see Mendes, J. (2011). Participation and the role of law after Lisbon: a legal view on article 11 TEU. Common Market Law Review 48 (6), pp. 1849-1878; Cuesta Lopez, v. (2010). The Lisbon Treaty's provisions on democratic principles: A legal framework for participatory democracy. European Public Law 16(1), pp. $123^{-138 .}$

2 Art. 11(4) TEU echoes Art. I-47(4) of the non-ratified Constitutional Treaty; see Sipala, F. (2007). La vie démocratique de l'Union. In: G. Amato, H. Bribosia and B. de Witte, eds., Genèse et destinée de la Constitution européenne, Brussels: Bruylant, p. 367; Dougan, M. (2011). What are we to make of the citizens' initiative? Common Market Law Review 48 (6), pp. 18071848,1808 .

3 See General Court, judgment of 10 May 2017, case T-754/14, Efler v. Commission, paras 24 and 37 .

4 Art. 1O(1) TEU.

5 See Art. 24 TFEU; General Court, judgment of 23 April 2018, case T-561/14, One of Us v. Commission, para. 72 and 93 . 
The effective functioning of citizens' initiatives could therefore strengthen the common identity of EU citizens and at the same time enhance the legitimacy of certain Commission proposals being initiated from citizens across the Union.

However, the impact of this instrument so far has been assessed as limited ${ }^{6}$ and the European Commission has been criticised for depriving the European citizens' initiative of its effectiveness due to its own institutional practice. ${ }^{7} \mathrm{On}$ this point, it is important to underline that the Commission's interpretation of the material scope of application of citizens' initiatives has been confirmed in four out of six cases brought before the General Court. ${ }^{8}$ The Commission has lost only once in substance, in the "Stop TTIP" case, ${ }^{9}$ and once for the procedural reason of lack of justification, in the "Minority SafePack" case. ${ }^{10}$ It is the latter case, as it will be shown, that has influenced more the general administrative practice, notably from a procedural point of view. Following this case-law and under pressure by the European Parliament, ${ }^{11}$ the European Ombudsman ${ }^{12}$ and other stakeholders, ${ }^{13}$ the Commission has revisited its

6 See the second Commission report to the European Parliament and Council on the application of Regulation (EU) No 211/2011, СОМ(2018) 157 final, p. 2.

7 See Salm, C. (2018). The added value of the ECI and its revision. European Parliament Research Service, PE 615.666, 13 April 2018, p. 11 et seq.

8 See General Court, judgment of 30 September 2015, case T-45o/12, Anagnostakis v. Commission, which was confirmed by Court of Justice, judgment of 12 September 2017, case C589/15 P, Anagnostakis v. Commission; General Court, judgment of 19 April 2016, case T-44/ 14, Constantini and others $v$. Commission; judgment of 5 April 2017, case T-361/14, HB and others v. Commission, which was confirmed by Court of Justice, judgment of 8 February 2018, case C-336/17 P, HB and others v. Commission. In case Izsak and Dabis v. Commission, the General Court ruled in favour of the Commission at first instance (judgment of 10 May 2015, case T-529/13, Izsak and Dabis v. Commission), but its judgment was set aside following an appeal before the Court of Justice, because the General Court had erroneously placed the burden of proof on the applicants as to whether the subject matter of their initiative was falling within the Commission competences to propose a legal act of the Union (Court of Justice, judgment of 7 March 2019, case C-420/16 P, Izsak and Dabis v. Commission, para. 72.) However, the Court of Justice confirmed in essence the Commission's interpretation of the Treaties (ibid. paras 70-71.).

9 Eflerv. Commission, cit.

10 General Court, judgment of 3 February 2017, case T-646/13, Minority SafePack v. Commission.

11 European Parliament Resolution P8_TA(2015)o382 of 28 October 2015 on the European Citizens' Initiative.

12 Own initiative report of the European Ombudsman of 4 March 2015, OI/9/2013/TN.

13 See for instance the opinion of the European Citizen Action Service (ECAS), Revising the ECI: How to make it fit for purpose, 20 April 2017, <www.euractiv.com/section/politics/ opinion/revising-the-eci-how-to-make-it-fit-for-purpose/ $>$. 
application practice towards a more flexible approach. ${ }^{14}$ In addition, it initiated a new Regulation governing the European citizens' initiative with a view to rendering this instrument more user-friendly and accessible to citizens. ${ }^{15}$

The timing of the Commission's revisited administrative practice and the initiation of the new Regulation coincide with the trigger of a series of Brexitrelated citizens' initiatives. EU citizens from different Member States have brought forward initiatives aiming either to reverse Brexit or to secure the rights of EU-citizens whose country withdraws from the EU. EU citizens with the nationality of the United Kingdom (UK) were able to organise and participate in European citizens' initiatives until the withdrawal of the UK from the EU. After the entry into force of the withdrawal agreement, namely on 1 February $2020,{ }^{16}$ UK nationals lost, inter alia, this political right, since Art. 11(4) TEU requires that participants of a European citizens' initiative are nationals of a Member State. It is noted that the withdrawal agreement excludes the applicability of the European citizens' initiative during the transition period. ${ }^{17}$

Given the wide public interest that Brexit has generated and the fact that six European citizens' initiatives have been Brexit-related, this group of initiatives ("Brexit-related initiatives") constitutes a suitable case study in order to illustrate the evolution of the Commission's administrative practice and assess it against general principles underpinning the functioning of EU institutions. It will be argued that the changed Commission's approach towards more flexibility takes better account of the primary law right of EU citizens to participate in the democratic life of the EU. However, a closer look at the way the revisited approach works in practice reveals shortcomings which interfere with the right to good administration and the principles of legal certainty and legitimate expectations. These principles will serve as normative benchmarks when assessing the Commission's practice.

Good administration is a general principle of EU law and a right enshrined in Article 41 of the Charter of Fundamental Rights of the EU (Charter), which guarantees that every person has their affairs handled impartially, fairly and within a reasonable time by the institutions, bodies, offices

14 See the second Commission report $\operatorname{com}(2018) 157$ final, cit., p. 2 on the non-legislative measures taken by the Commission.

15 Commission Proposal for a Regulation of the European Parliament and of the Council on the European citizens' initiative,

16 See https://ec.europa.eu/info/european-union-and-united-kingdom-forging-new-partnership/ eu-uk-withdrawal-agreement_en

17 See Article 127(1) (b) of the Withdrawal Agreement.applicability in the United Kingdom of EU law on the European citizens' initiative during the transition period. 
and agencies of the Union. ${ }^{18}$ This right also generates an obligation of the administration to inform adequately all involved persons in an ongoing administrative procedure. ${ }^{19}$ From a broader perspective, good administration is connected with good governance and requires that the administration conducts a transparent information policy and provides guidance and assistance to the public. ${ }^{20}$

Legal certainty requires that legal rules and acts are clear and precise, and that legal relationships governed by Community law remain foreseeable. ${ }^{21}$ While legal certainty refers to the clarity and foreseeability of the legal framework, the principle of the protection of legitimate expectations concerns the ability to rely on the presumed legality of individual measures and on precise assurances provided by the competent administrative organs. ${ }^{22}$

In the following sections, the role of the Commission as institutional mediator of European citizens' initiatives will be assessed against these principles, which form the procedural guarantees for the effective exercise of this participatory right. The cycle of a European citizens' initiative will be divided

18 See Court of Justice, judgment of 4 April 2017, case C-337/15 P, Ombudsman v. Staelen, para. 34 .

19 See Art. 41, para. 1, let. b), of the Charter on the access to the file which encompasses a more general information obligation; on this obligation see Harlow, C. and Rawlings, R. (2014) Process and Procedure in EU Administration. Oxford: Hart Publishing, p. 88.

20 On the elements of good governance see Art. 15 TFEU. On the connection between good administration and good governance see Hofmann, H., Rowe, G. and Türk, A. (2011). Administrative law and policy of the EU. Oxford: Oxford University Press, p. 461; Harlow, C. and Rawlings, R. (2014). Process and Procedure in EU Administration. cit., p. 209. As example of the obligation of assistance and guidance to the public see Art. 1, para. 2, of Regulation (EC) No 1367/2006 of the European Parliament and of the Council of 6 September 2006 on the application of the provisions of the Aarhus Convention on Access to Information, Public Participation in Decision-making and Access to Justice in Environmental Matters to Community institutions and bodies, OJ L 264, 25.9.2006, p. 13-19.

21 See Court of Justice, judgment of 15 September 2005, case C-199/o3, Ireland v. Commission, para 69; judgment of 29 October 2009, case C-29/o8, $S K F$, para. 77; See also Tridimas, T. (2006). The General Principles of EU Law. Oxford: Oxford University Press, p. 242; Hofmann, H., Rowe, G. and Türk, A. (2011). Administrative law and policy of the $E U$, cit., p. 173 .

22 See inter alia Court of Justice, judgment of 16 June 1966, case 54/65, Châtillon v. High Authority; judgment of 19 May 1983, case 289/81, Mavrides v. Parliament; judgment of 20 March 1997, case C-24/95, Land Rheinland-Pfalz v. Alcan Deutschland. See also Sharpston, E. (1990-1991). European Community Law and the Doctrine of Legitimate Expectations: How Legitimate, and for Whom. Northwestern Journal of International Law \& Business 11, pp. 87-103. 
in two phases: the registration phase, in which the Commission applies the socalled admissibility test (section II), and the post-registration phase, in which the collection of signatures takes place and the Commission pronounces on an eventually successful initiative (section III). In the last section, the Brexitrelated initiatives will be used as a case study illustrating the evolution of the Commission's practice towards more flexibility and the shortcomings which still remain (section IV).

\section{Revisiting the Admissibility Test}

The right to put in place a European citizens' initiative as enshrined in Art. 11(4) TEU was rendered concrete through Regulation (EU) 211/2011 of the European Parliament and of the Council of 16 February 2011, which was adopted on the basis of Art. 24(1) TFEU and entered into force on 1 April 2012. ${ }^{23}$ Regulation (EU) 211/2011 was replaced by Regulation (EU) 2019/788 ("new Regulation"), which entered into force on 1 January 2020. Regulation (EU) 211/2011 remains in force for ongoing initiatives. ${ }^{24}$ Since this chapter discusses initiatives which were put place on the basis of Regulation (EU) 211/2011, reference is primarily made to this Regulation.

The procedure which citizens have to follow contains several steps: as a first step, the organisers of an initiative who must be EU citizens and residents of at least seven different Member States (Art. 3 Regulation (EU) 211/2011) are required to apply for registration in the Commission's online register by submitting information on the subject matter and the objectives of the proposed initiative (Art. 4 Regulation (EU) 211/2011). The Commission has two months to examine the proposed initiative and check whether certain admissibility conditions are fulfilled (Art. 4(2) Regulation (EU) 211/2011). If the initiative is found admissible and is registered by the Commission, the signature collection process begins (Art. 5 Regulation (EU) 211/2011). The organisers must collect within 12 months at least one million signatures from at least one quarter of

23 Regulation (EU) 211/2011 of the European Parliament and of the Council of 16 February 2011 on the citizens' initiative, OJ L 65, 11.3.2011, p. 1-22. For critical remarks on Regulation 211/2011, see Dougan, M. (2011). What are we to make of the citizens' initiative?, cit., p. 1807; Kaufmann, B. (2012). Transnational Babystep: The European citizens' initiative. In: T. Schiller and M. Setala, eds., Citizens' Initiatives in Europe; Procedures and consequences of agenda-setting by citizens, London: Palgrave Macmillan, p. 229.

24 See Art. 26-27 Regulation (EU) 2019/788 of the European Parliament and the Council of 17 April 2019 on the European citizens' initiative, OJ L 130, 17.5.2019, p. 55-81. 
Member States (Art. 7 Regulation (EU) 211/2011). Once all the conditions relating to the collection of signatures have been fulfilled and verified (Art. 8), the organisers may submit the initiative to the Commission for its consideration (Art. 9 Regulation (EU) 211/2011). The Commission publishes it and receives the organisers who can now explain their proposal in detail (Art. 10(1), let. a) and b), Regulation (EU) 211/2011). In addition, a public hearing is organised at the European Parliament with the participation of other institutions, the Commission included (Art. 11 Regulation (EU) 211/2011). Finally, within three months following the submission, the Commission sets out in a communication its legal and political conclusions on the initiative, the action it intends to take, if any, and its reasons for taking or not taking that action (Art. 10(1), let. c), Regulation (EU) 211/2011).

From this brief outline of the procedure, it becomes apparent that the role of the Commission is crucial at two stages, at the very beginning, at the stage of the admissibility check, and at the very end, when the Commission decides which action it intends to take in order to give effect to a successful initiative (follow-up stage).

The admissibility test encompasses one positive procedural and three negative substantive conditions. The procedural condition requires that the organisers have formed a citizens' committee of at least seven persons who are residents of at least seven different Member States (Art. 3 and 4(2), let. b), Regulation (EU) 211/2011). The substantive conditions concern the subject matter of the initiative and require that it is not manifestly abusive, frivolous or vexatious (Art. 4(2) let. c), Regulation (EU) 211/2011), it is not manifestly contrary to the values of the Union as set out in Art. 2 TEU (Art. 4(2), let. d), Regulation (EU) 211/2011) and, most importantly, as directly dictated by primary law, it does not manifestly fall outside the framework of the Commission's powers to submit a proposal of a legal act of the Union for the purpose of implementing the Treaties.

This latter condition has proven to be the main hurdle for organisers to achieve formal registration of their initiative and it has generated a series of judgments of the General Court. Twenty eight initiatives ${ }^{25}$ have been refused registration so far because, according to the Commission's justification, no legal basis in the Treaties could support a legal act of the Union on their subject matter, three of which were in the end (partially) registered following a Court judgment. ${ }^{26}$

25 Available at <www.ec.europa.eu/citizens-initiative/public/initiatives/non-registered>.

26 The Initiatives "Stop TTIP", "Minority SafePack" and "Cohesion policy for the equality of the regions and sustainability of the regional cultures". 
Various stakeholders, including citizens' organisations, ${ }^{27}$ academics, ${ }^{28}$ the European Parliament ${ }^{29}$ and the European Ombudsman ${ }^{30}$ had urged the Commission, before the introduction of the new Regulation, to reconsider its practice by offering better guidance to organisers and applying the admissibility test in a less strict way, so as to increase the number of successful registrations.

In the following sub-sections, two landmark judgments, which bear also importance for initiatives in the context of the Brexit negotiations, will be analysed: firstly, the judgment in case "Minority SafePack", which opened the way for partial registration of citizens' initiatives (II.1.); secondly, the judgment in case "STOP TTIP", which enabled the registration of initiatives aiming to influence ongoing negotiations of international agreements (II.2.). These evolutions will be assessed against the right to participation and the general principles of good administration, legal certainty and protection of legitimate expectations.

\section{II.1 Possibility of Partial Registration}

The main problem in the initial registration practice had been that the Commission perceived an initiative as an inseparable package leading to either acceptance or rejection of the initiative as a whole, without assessing each of its different components. ${ }^{31}$ It seemed to apply a centre of gravity test on whether the essence of the initiative lied with the admissible or the nonadmissible part and decide accordingly. ${ }^{32}$ This approach prevented initiators from understanding which of the elements of their proposal could possibly qualify for resubmission, in order to come back with a new admissible project. ${ }^{33}$ The opportunity for the Commission to reconsider this practice was given with the judgment of the General Court in case "Minority SafePack". With this judgment the General Court annulled the Commission's decision refusing the registration of the initiative "Minority SafePack" on the formal ground of lack of justification, because the Commission did not specify which elements of the initiative where admissible and which were not (incomplete statement

27 See for instance the opinion of the European Citizen Action Service (ECAS), cit.

28 Organ, J. (2014). Decommissioning direct democracy? European Constitutional Law Review 10 (3), pp. 422-443; Karatzia, A. (2015). The European citizens' initiative in practice: legal admissibility concerns. European Law Review 40 (4), pp. 251-270.

29 European Parliament Resolution (2015)O382, cit.

30 Own initiative report of the European Ombudsman of 4 March 2015, OI/9/2013/TN.

31 See for the Commission's interpretation Minority SafePack v. Commission, cit., para. 21.

32 See for the Commission's position Minority SafePack v. Commission, cit., para. 28.

33 See this argument in Minority SafePack $v$. Commission, cit., para. 29. 
of reasons). ${ }^{34}$ The General Court left open the legal consequences of partial admissibility. ${ }^{35}$ Two different options seemed to be possible, namely that partial admissibility leads to full rejection if the inadmissible content constitutes the essence of the initiative, or to partial registration if the content is indeed separable. As for the possibility of partial registration, it could also be argued that this should not be decided alone by the Commission, but that the latter should confer with the organisers whether they consent to partial registration.

The Commission's practice following the judgment in case "Minority SafePack" shows that, from this point onwards, the Commission identifies the elements of the initiative on which it could make a proposal for an act of the Union and accepts registration for these parts. ${ }^{36}$ This evolution is welcome and indeed enables the registration of more initiatives, while respecting the principle of conferral of Union powers (Art. 5 TEU). Partial registration also takes better account of the principle of legitimate expectations, since the registered initiative is cleared from its inadmissible parts and therefore both the organisers and potential signatories have in this way an accurate picture of what they can achieve through their initiative.

However, the problem in the implementation of this practice is that the content of the initiative which is registered in the official Commission register (public website) is not adjusted to the Commission's decision to accept only part of the initiative, but it continues to include the inadmissible parts. ${ }^{37}$ The webpage contains a disclaimer that the contents of the page are the sole responsibility of the organisers of the initiatives and they can in no way be taken to reflect the views of the Commission. However, this approach leads to the result that the official register does not provide a clear image of the admissible content of initiatives. This could have the negative effect of creating false expectations for those signatories who sign an initiative on the basis of the

34 Minority SafePack v. Commission, cit., para. 29. For a detailed analysis, see Inglese, M. (2018). Recent trends in European Citizens' Initiatives: The General Court case-law and the Commission's practice. European Public Law 24 (2), p. 335.

35 See Minority SafePack v. Commission, cit., para. 29. This open outcome is in line with Article 266(1) TFEU which provides that the institution draws the consequences of the annulment of its act.

36 See the Commission Decision C(2017) 2200 of 29 March 2017 on the partial registration of the initiative "Minority SafePack", following the judgment in Minority SafePack v. Commission, cit.; see also the Commission Decision C(2017) 3382 of 16 May 2017 on the partial registration of the proposed citizens' initiative entitled "Let us reduce the wage and economic differences that tear the EU apart!".

37 See for instance the description of the initiative "Minority SafePack" following its partial registration, available at <http://ec.europa.eu/citizens-initiative/public/initiatives/open/ details/2017/000004>. 
content featured on the website without looking concretely into the Commission decision of registration.

This recent practice of partial registration is now crystallised in the new Regulation, which proposes a fully-fledged mechanism of exchange of views between the Commission and the organisers, when upon request of registration of an initiative the Commission considers that the whole or parts of the initiative manifestly fall(s) outside of the Commission's powers, with a view to enabling at least partial registration of the initiative. ${ }^{38}$ This proposed mechanism of interaction between the Commission and the organisers is of major importance, because it will allow organisers to know in advance the Commission's position on the admissibility of their initiative, so as to adjust the content accordingly in order to achieve successful registration. Currently, such exchanges of views and clarifications regarding the content of the proposal appear to happen for the first time before the General Court, when the organisers challenge the non-registration of their initiative. This situation is an obstacle to effective democratic participation and is not considered to be in line with the principle of good administration in the broad sense, which as outlined above, ${ }^{39}$ requires the provision of assistance and guidance to interested citizens. The importance of this principle in the context of European citizens' initiatives has been already stressed by the Court. ${ }^{40}$ It is thus welcome that the new Regulation includes an administrative phase of exchange of views between the Commission and the organisers.

The new Regulation also provides that, when partial registration takes place, the organisers shall ensure that potential signatories are informed of the scope of the registration and of the fact that statements of support are collected only in relation to the scope of the registration of the initiative. ${ }^{41}$ This provision is also of major importance towards achieving transparency and clarity about the final admissible content of an initiative, since, as already mentioned, organisers have not been adjusting the information provided in the official Commission register following a partial registration.

\section{II.2 Possibility of Influencing Ongoing Negotiations}

A second important judgment, which bears significance also for initiatives in the context of Brexit, is the judgment in the case "STOP TTIP". The organisers of the initiative "Sтор тTIP" requested the Commission inter alia to withdraw

$3^{8} \quad$ See Art. 6, para. 4, Regulation (EU) 2019/788.

39 See section I.

40 See Anagnostakis v. Commission, case C-589/15 P, cit., para. 47.

41 See recital 19 and Art. 6, para. 5, Regulation (EU) 2019/788. 
its recommendation to the Council to authorise the opening of negotiations for the Transatlantic Trade and Investment Partnership (ттіP).$^{42}$ The Commission rejected the request for registration on the basis of two arguments.

First, the Commission supported the view that Art. 11(4) TEU refers only to formal Commission proposals leading to the adoption of final acts of the Union producing legal effects vis-à-vis third parties; it thus excludes Commission recommendations which aim at the adoption of preparatory acts by another institution producing effects only among the institutions, such as the Council decision authorising the opening of negotiations. ${ }^{43}$ This Council decision adopted on the basis of Art. 218(3) TEU was perceived by the Commission as a preparatory/intermediate act; the final act of the procedure leading to the adoption of an international agreement would be the Council decision authorising the Commission to conclude the agreement. ${ }^{44}$

The second Commission's argument was that "negative acts" may be the object of citizens' initiatives only if they seek to amend or repeal existing acts, because Art. 11(4) TEU provides that initiatives should aim at the adoption of an act required for implementing the Treaties (emphasis added). For this reason, according to the Commission, it is not possible for citizens to reunite in order to stop the institutions from acting for the first time. ${ }^{45}$

The General Court, following an action for annulment by the organisers of the "ST OP TTIP" initiative, ruled that citizens could also invite the Commission on the basis of Art. 11(4) TEU to submit recommendations for any act of the Union, including acts which deploy legal effects only among institutions, since the provision of the Treaties does not contain any indication to the contrary. ${ }^{46}$ This conclusion was reinforced by the argument that the Council decision authorising the opening of negotiations constitutes a decision in the sense of Art. $288 \mathrm{TFEU}$ and thus an "act of the Union" in the meaning of Art. 11(4) TEU. ${ }^{47} \mathrm{It}$ is important to note that the General Court used the principle of democracy as a guiding principle when interpreting the legal framework, which is specifically pursued by the instrument of the European citizens' initiative. This principle requires, according to the judgment, a broad interpretation of the term "legal act of the Union", so as to enable citizens' participation in all legal acts which

42 See Commission Decision C(2014) 6501 of 10 September 2014 on the registration of the initiative "stop TTIP", p.1.

43 Ibid., p. 3.

44 Ibid., p. 2.

45 Ibid.

$46 \quad$ Eflerv. Commission, cit., para. 35 .

47 Ibid., para. 36. 
seek to modify the legal order of the Union, such as the acts preparing the conclusion of an international agreement. ${ }^{48}$

It follows from this judgment that the General Court interpreted the term "proposal" for an act of the Union, as used in Art. 11(4) TEU, in a "non-technical" way and beyond the limits of Art. 17(2) TEU, thus including also Commission recommendations or possibly other acts, with which the Commission gives its opinion to another institution for the adoption of any legal act of the Union. This broad interpretation of the term "proposal" could also be based on the wording of Art. 11(4) TEU which refers to "any appropriate proposal" by the Commission, leaving the specific instrument open. It is interesting to note that the wording of Regulation 211/2011 appears to be more restrictive in this sense referring to " $a$ proposal" by the Commission and not "any appropriate proposal" as in primary law [emphasis added].

The General Court dismissed also the second argument of the Commission with the justification that the objective of participation in the democratic life of the Union pursued by the mechanism of the European citizens' initiative manifestly includes the power to request the amendment or withdrawal of legal acts, such as the Council decision authorising the opening of negotiations with a view to concluding an international agreement. Acts whose object it is to prevent the signing and conclusion of such an agreement produce, according to the General Court, independent legal effects by preventing, as the case may be, an announced modification of European Union law. ${ }^{49}$ The General Court also noted, that, were the Commission's opinion to be followed, the absurdity would be that citizens would have to await the conclusion of an international agreement, so as to be able to invite the institutions to end it. ${ }^{50}$

This judgment bears significant importance, since it clarifies the material scope of the European citizens' initiative. By using the principle of democracy as a normative benchmark, the Court interprets Art. 11(4) TEU in the broadest possible way, with a view to enabling citizen involvement also in the area of ongoing negotiations. The straightforward interpretation of the term "legal act" as encompassing any legal act of the institutions strengthens not only participatory democracy but also legal certainty, because it avoids classifying EU

48 Ibid., para. 37. The principle of democracy was used as interpretation guideline also in previous cases, see Anagnostakis v. Commission, case T-45o/12, cit., para. 26; Constantini and others v. Commission, cit., para. 73; Minority SafePack v. Commission, cit., para. 18.

49 Efler v. Commission, cit., para. 43. Following this judgment, the Commission registered the initiative "STOP TTIP" with Commission Decision C(2017) 4725 of 4 July 2017 on the proposed citizens' initiative entitled "Stop TTIP". 
legal acts in categories which would be difficult for potential organisers and citizens to follow.

\section{Managing Expectations at the Post-Registration Stage}

The organisers of an initiative, even after they have cleared the hurdle of admissibility and have managed to gather the necessary number of signatures, have still no guarantee that the Commission will take action in line with their proposal. It is clear from the wording of Art. 11(4) TEU ("inviting") that the Commission enjoys discretion on whether to follow the proposal made by the citizens and which exact action to take ("any appropriate proposal").51 This means that the instrument of citizens' initiatives constitutes an agenda setting tool and not a way to formally initiate the adoption of a legal act. ${ }^{22}$ The right of initiative remains with the Commission. This interpretation according to which the Commission has no legal obligation to make a proposal following the invitation of a successful initiative was confirmed by the recent judgments in the case "One of Us", both by the General Court and by the Grand Chamber of the Court of Justice upon appeal of the organisers. ${ }^{53}$ The choice made by the Treaty not to confer to an ECI a formal right of initiative can be explained through the Commission's role in the EU institutional balance. ${ }^{54}$ Pursuant to Art. $17 \mathrm{TEU}$, the Commission is in charge - inter alia - of safeguarding the general interest of the EU, ensuring respect of the Treaties (Art. 17(1) TEU) and initiating the adoption of Union legal acts (Art. 17(2) TEU). It follows from this last point that the Commission is also responsible for ensuring the coherence

51 Compare the wording of Art. 11(4) TEU with Art. 225 TFEU on the equivalent right of the European Parliament and Art. 241 TFEU on the equivalent right of the Council, which both use the term "requests". See the preparatory works of the Constitutional Treaty, during which the initial term "requests" was replaced with the term "invites" in Art. I46 of the draft Constitutional Treaty on the European citizens' initiatives, 12 June 2003, CONV 811/o3, p. 5. On this, see also Hieber, T. (2014) Die Europäische Bürgerinitiative nach dem Vertrag von Lissabon. Tübingen: Mohr Siebeck, p. 9.

$5^{2}$ On this agenda-setting function, see Organ, J. (2014). Decommissioning direct democracy?, cit., p. 424.

53 One of Us v. Commission, cit., paras 111 and 122. The judgment of the General Court was confirmed by the Court of Justice, judgment of 19 December 2019, case C-418/18 P, Puppinck and Others v. Commission (One of Us).

54 On the "institutional balance" within the EU, see Court of Justice, judgment of 13 June 1958, case 9/56, Meroni v. High Authority, p. 152; judgment of 14 April 2015, case C-409/13, Council v. Commission, para. 64; Eflerv. Commission, cit., para. 46; One of Us v. Commission, cit., paras 110 et seq. 
of EU policies and actions ${ }^{55}$ on the basis of the Union's annual and multiannual programming (Art. 17(1) TEU). ${ }^{56}$ Thus, an initiative launched by citizens which contradicts a policy line, especially one based on existing legislation, ${ }^{57}$ would provoke a public debate on the issue, but would not necessarily oblige the Commission to change its policy line.

Only five initiatives have so far collected the required one million signatures. ${ }^{58}$ The Commission in its communications ${ }^{59}$ as a follow-up to these successful initiatives committed itself to further strengthening and improving the existing legal framework in the relevant subject matter, but it has been reproached for not fulfilling (all) the objectives of the organisers and for not initiating any new legislation apart from amendments to existing provisions. ${ }^{60}$

The organisers of the initiative "One of Us" aiming to end the financing of activities which presuppose the destruction of human embryos, in particular in the areas of research, development aid and public health, have been the first to challenge the Commission's Communication ${ }^{61}$ on its intended follow-up (non) action before the General Court. The Commission argued before the Court that its communications on its intended action or non-action do not constitute

55 See Councilv. Commission, cit., para. 87.

$5^{6}$ On the Union's annual and multiannual programming see Martenczuk, B. (2019). Art. 17 EUV. In: E. Grabitz, M. Hilf and M. Nettesheim, eds., Das Recht der EU, Munich: C. H. Beck, para. 51.

57 See the Commission's argument in One of Us v. Commission, cit., para. 151.

$5^{8}$ The initiative "Right2Water" on achieving universal access to water and sanitation and on exempting water supply and management from internal market rules; the initiative "Stop Vivisection" with the aim to phase out animal experiments for scientific purposes; the initiative "One of us" aiming to ban and end the financing of activities which presuppose the destruction of human embryos and the initiative "Ban glyphosate" aiming to ban glyphosate-based herbicides and improve the EU regulatory framework for evaluation of pesticides; lastly, the initiative "Minority SafePack", which calls upon the EU to improve the protection of persons belonging to national and linguistic minorities and strengthen cultural and linguistic diversity in the Union. All five initiatives can be found at $<w w w$. ec.europa.eu/citizens-initiative/public/initiatives/successful>.

59 The Commission Communications can be found at <www.ec.europa.eu/citizensinitiative/public/initiatives/successful>.

6o See Karatzia, A. (2017). The European citizens' initiative and the EU institutional balance: on realism and the possibilities of affecting EU lawmaking. Common Market Law Review 54 (1), pp. 177-208, 198; Bélier, S. (2014). Fulfilling the promise of the ECI, learning from the Right 2 Water experience. In: C. Berg and J. Thomson, eds., An ECI that works! Learning from the first two years of the European citizens' initiative, Germany: Alfter, p. 81. On the follow-up action of the Commission to the so far successful initiatives, see the second Commission report Сом(2018) 157 final, cit., p. 10 et seq.

61 Commission Communication $\operatorname{COM(2014)~} 355$ of 28 May 2014 on the European Citizens' Initiative "One of us". 
reviewable acts, because they do not produce legal effects capable of affecting the interests of the applicants by bringing about a distinct change in their legal position. ${ }^{62}$ Contrary to the Commission's contentions, the Court ruled that such communications are indeed reviewable, because they are the closure act of an administrative procedure, which the Commission is obliged to issue while respecting certain procedural guarantees, such as the obligation to state reasons. ${ }^{63}$ The General Court allowed judicial review so as to control the respect of these procedural guarantees, while noting that such review is of a limited nature given the wide margin of appreciation enjoyed by the Commission. ${ }^{64}$

Assessing the Commission's follow-up practice to date against the principles of good administration, legal certainty and legitimate expectations, two lessons can be learnt, which might help managing expectations for future successful initiatives and are relevant for Brexit-related initiatives.

\section{III.1 False Expectations in Case of Partially Inadmissible Initiatives}

In the case of two successful initiatives, the Commission indicated in its Communications to the organisers at the very late stage of follow-up that it could not take any action for part of the aims of the initiatives, since they were Member State rather than EU competencies. More specifically, this concerned one of the aims of the initiative "Right 2 Water" to exempt water supply and management from privatisation ${ }^{65}$ and the part of the initiative "One of us" aiming to ban and end the financing of activities which presuppose the destruction of human embryos for research purposes. ${ }^{66}$ The fact that these initiatives were fully registered despite containing certain inadmissible elements created false expectations for the organisers, the signatories as well as the general public that the Commission is competent to propose legislation in line with the initiatives. The Commission has been criticised for not fulfilling (all) the objectives of the organisers and for not initiating any new legislation in this regard, ${ }^{67}$ although

\footnotetext{
62 One of Us v. Commission, cit., para. 69.

63 One of Us v. Commission, cit., paras 77 et seq.

64 One of Us $v$. Commission, cit., paras 169-170.

65 See Commission Communication $\operatorname{com}(2014) 177$ of 19 March 2014 on the European Citizens' Initiative "Water and sanitation are a human right! Water is a public good, not a commodity!".

66 See Commission Communication $\operatorname{com}(2014) 355$.

67 See the reaction of the "Right2Water" citizens' committee at <http://www.right2water.eu/news/press-release-commission-lacks-ambition-replying-first-europeancitizens\%E2\%80\%99-initiative $>$. See among the academic commentators Karatzia, A. (2017). The European citizens' initiative and the EU institutional balance, cit., 198; Bélier, S. (2014) Fulfilling the promise of the ECI, cit., p. 81; Vogiatzis, N. (2017). Between
} 
the real problem was the creation of false expectations from the outset. This example illustrates the importance of clearing the admissibility of the main aims of an initiative at the registration phase. Otherwise, the early admissibility check loses its rationale. The recent Commission practice of clearing the inadmissible parts through partial registration, as explained above, is expected to bring more clarity to the organisers and potential signatories of what they can reasonably expect as the outcome of their initiative.

\section{III.2 Difficulty of Influencing Ongoing Procedures}

Another situation which can create frustration and disappointment for organisers is where they aim to influence ongoing procedures, such as the negotiation or signature of international agreements. In the case of the initiative "sтоP TTIP", the organisers invited the Commission to recommend to the Council to repeal the negotiating mandate for the TTIP and not to conclude the Comprehensive Economic and Trade Agreement (CETA). The request for registration was made in July 2014, whereas in August 2014 the negotiations for CETA were already concluded and the negotiating mandate for TTIP had already been approved by the Council one year before the request for registration. ${ }^{68}$

Even assuming that there was the political will to repeal the negotiating mandate for TTIP, it is legally unclear whether the Commission has the power to return to the Council with a new recommendation after the Council has already approved the negotiating mandate. More precisely, Art. 293(2) TFEU provides that the Commission can amend its proposals as long as the Council has not acted. The same was held by the Court of Justice as regards the Commission's right to withdraw its proposals under certain conditions. ${ }^{69}$ The Commission must respect this requirement also when it amends or withdraws a proposal following the invitation of a citizens' initiative, meaning that the withdrawal or amendment must take place before the Council has acted, since the Treaty provision does not contain any exceptions. Here, the question arises whether the same limitation should apply also when citizens invite the Commission to amend or withdraw its recommendation after the Council has already acted. In case this limitation of Art. 293(2) TFEU is to be applied mutatis mutandis also in the context of Art. 218(3) TFEU, it is highly doubtful that the

discretion and control: Reflections on the institutional position of the Commission within the European citizens' initiative process. European Law Journal 23 (3-4), pp. 250-271, 261; Inglese, M. (2018). Recent trends in European Citizens' Initiatives, cit., p. $35^{8}$.

68 On the facts, see Eflerv. Commission, cit., para. 1.

69 Council v. Commission, cit. On this judgment, see Ritleng, D. (2016) Does the European Court of Justice take democracy seriously? Common Market Law Review 53 (1), pp. 11-33. 
Commission can come back with a new recommendation advising the opposite course of action to that it recommended previously.

The judgment of the General Court does not deal with these aspects at all, stating in a rather minimal way that the citizens' initiative "STOP TTIP" is "far from amounting to an interference in an ongoing legislative procedure". ${ }^{70}$ It can be derived from this that the General Court assessed in abstracto whether the Commission has a general competence in the subject matter of the initiative without taking into account in concreto whether it would be able to submit any appropriate proposal on this matter in terms of timing. The aspect of timing is of particular importance bearing in mind that the organisers also need time for the collection of signatures (a maximum of one year). ${ }^{71}$

The case of "Sтор тTIP" shows that the lengthy procedure of a European citizens' initiative does not seem to be best suited for quick reactions from citizens with a view to blocking ongoing procedures. Therefore, it is difficult to imagine that a citizens' initiative could successfully block the ongoing procedure in relation to the conclusion of an international agreement, since the gathering of signatures has no suspensive effect on the actions of the institutions.

In sum, the Commission has in recent years been urged to become more open and flexible when interpreting the admissibility of ECI s. This is a welcome development, but it raises a set of new challenges to protect the legitimate expectations of organisers and signatories as to the real potential of their initiatives. We can therefore observe a tension between a generous admissibility control with a view to enhancing participation and the need to adequately inform the public of what can be actually and pragmatically achieved at the end of the process. The difficulty of solving this tension by striking the right balance is evident also in the case of Brexit-related initiatives. It will be shown that Brexit-related initiatives have benefitted from the Commission's more open approach when applying the admissibility test as it has developed after the aforementioned judgments in cases "Minority SafePack" and "sтор TTIP", but that no measures have been taken in order to manage the expectations of the citizens involved.

Brexit-related initiatives which have requested registration from the European Commission can be divided into two categories: first, initiatives aiming directly

$\begin{array}{ll}70 & \text { Eflerv. Commission, cit., para. 47. } \\ 71 & \text { See Art. 5(5) of Regulation 211/2011. }\end{array}$ 
or indirectly at reversing the decision of the UK to withdraw from the EU, and, second, initiatives aiming at securing the rights of citizens whose countries withdraw from the EU. The Commission has applied a strict admissibility test to the first category stressing the sovereign power of the UK regarding the withdrawal decision, while it has shown considerable openness and flexibility vis-à-vis the second category.

\section{IV.1 Towards a More Flexible Admissibility Test}

The category of initiatives aiming directly or indirectly at reversing the decision of the UK to withdraw from the EU consists of the initiatives "sTop Brexit" and "British friends-stay with us in EU". The main aim of the initiative "sтоP Brexit" is that the UK stays in the European Union, without any further specification. ${ }^{72}$ As regards the second initiative in this category, "British friendsstay with us in EU", its main aim is to "create a platform which would enable all European citizens to take part in this initiative and to reach a majority of British citizens (including those which live in the EU who were effectively disenfranchised in the original referendum) thereby giving to all British citizens an opportunity to voice their opinion".73

The Commission rejected registration of both initiatives with the argument that there is no legal basis in the Treaties which would allow for the adoption of a legal act of the Union in order to prevent a Member State from withdrawing from the Union, since the withdrawal decision is a sovereign decision of Member States according to their own constitutional requirements pursuant to Art. $50(1)$ TEU. ${ }^{74}$ This argumentation appears to be self-evident for the initiative "sтор Brexit". However, the answer as regards the admissibility of the initiative "British friends-stay with us in EU" does not seem to be straight-forward. This initiative does not request that the Commission adopts an act in order to prevent the withdrawal of the UK, but merely the creation of a platform which will unite EU citizens against the Brexit outcome. The exact mission of this platform is not entirely clear; however, the initiative seems to request facilitation in order to unify the voices of British citizens against Brexit. It thus seems to invite the Commission not to adopt a legal act, but to proceed to a "material act", the creation of a platform.

72 Available at <http://ec.europa.eu/citizens-initiative/public/initiatives/non-registered/ details/3511>.

73 Available at <http://ec.europa.eu/citizens-initiative/public/initiatives/non-registered/ details/4061>.

74 Commission Decision C(2017) 2000 of 22 March 2017 on the proposed citizens' initiative entitled "Stop Brexit". 
The instrument of the European citizens' initiative should aim, according to Art. 11(4) TEU, at the adoption of legal acts. The Commission's previous practice shows that the Commission does not exclude taking also measures other than the adoption of legal acts, such as the organisation of conferences, in order to fulfil the aims of an initiative. ${ }^{75}$ However, such measures seem to be of a supplementary or preparatory nature vis-à-vis the adoption of a legal act. Therefore, it can be concluded that an initiative which aims exclusively at a "material" or "simple" act, such as the creation of a platform, and not of a legal act of the Union, falls outside the scope of the Art. 11(4) TEU. Even though the outcome is the same, the Commission's justification of the rejection of the initiative does not seem to be reflecting the real content of the initiative, leaving the organisers without any sufficient explanation. The situation of unclarity as to the material scope of a European citizens' initiative hampers legal certainty. The Commission missed the opportunity to clarify whether Art. 11(4) TEU fully excludes "material acts" or allows them only complementary, in conjunction with legal acts. This question apparently continues to remain perplexing for citizens.

The second category of initiatives, aiming at securing the rights of citizens whose countries withdraw from the EU, comprises four initiatives. All four initiatives managed to pass the hurdle of admissibility. The first initiative, registered as "European Free Movement Instrument" (known also as the "Choose Freedom initiative"), aimed at giving UK nationals EU passports in the form of a unified laissez-passer document, ${ }^{76}$ similar to the laissez-passer document currently issued for EU officials and other staff members of the EU.77 According to the Commission's press communication, the College of Commissioners decided to register this initiative, concluding that a legal act of the Union with the content of this initiative could indeed be adopted under the current Treaties. ${ }^{78}$ The justification of this positive decision is indeed not evident, especially if it is taken into account that the legal basis of issuance of the current laissez-passer documents is Protocol No 7 on the privileges and immunities of the European Union, which aims to facilitate the functioning of the EU institutions, by conferring inter alia certain rights to their staff members. It is thus left unanswered under which basis a legal act of the Union conferring EU

75 See C(2015) 3773 of 3 June 2015 on the European Citizens' Initiative "Stop Vivisection".

76 Available at <http://ec.europa.eu/citizens-initiative/public/initiatives/obsolete/details/ 2017/000001>.

77 See Council Regulation (EU) No 1417/2013 of 17 December 2013 laying down the form of the laissez-passer issued by the European Union, OJ L 353, 28.12.2013, p. 26-39. 
passports to non-EU citizens who are not employees of the institutions could be adopted.

This decision is diametrically opposed to the previous Commission practice, during which the Commission was examining in a very thorough and detailed way the possible legal bases for an initiative, without taking positive registration decisions in abstract terms, i.e. without having concretely identified at least one legal basis which could support the aim of the initiative. ${ }^{79}$ Furthermore, it is the first time that the press communication refers to a decision of the "College of Commissioners" 80 and that the decision is signed on behalf of the College by the first Vice-President F. Timmermans, while all the previous decisions concerning the registration of European citizens' initiatives were signed by the Commission's Secretary General. This new practice of signature by the competent Vice-President has continued for all subsequent registration decisions to date, demonstrating a clear intention of the Commission to retain control of the admissibility practice at the highest level and to show to the public that it highly values the instrument of the European citizens' initiative. This change of practice is explicitly mentioned in the second Commission report to the European Parliament and Council on the application of Regulation $211 / 2011.81$

It is not surprising that this both procedural and substantive change of practice began after the hearings in cases "Minority SafePack" and "ST OP TTIP" and shortly before the General Court delivered its judgments in these cases, annulling the Commission decisions not to register the initiatives at stake. For all these reasons, the positive decision of the Commission registering the "European Free Movement Instrument" initiative seems to mark a new era as regards the Commission's practice when assessing the admissibility of initiatives.

This new approach, showing considerable openness when assessing whether the Treaties contain a legal basis which could support the object of the initiative, was confirmed also in three subsequent initiatives related to Brexit and citizens' rights. With the initiative "EU-citizenship for Europeans: United in Diversity in Spite of jus soli and jus sanguinis" (informally known as "Flock Brexit"), the organisers aimed at separating EU citizenship and nationality. ${ }^{82}$ In a similar vein, the aim of the initiative "Retaining European Citizenship"

79 See also the facts mentioned in Constantini and others v. Commission, cit., para. 54, as regards the Commission's detailed assessment of possible legal bases.

8o Brussels, 21 December 2016, IP/16/4436.

81 Second Commission report сом(2018) 157 final, cit., p. 5 .

82 Available at <http://ec.europa.eu/citizens-initiative/public/initiatives/obsolete/details/ 2017/000003>. 
was to "retain the rights of EU citizenship for all those who have already exercised their freedom of movement prior to the departure of a Member State leaving the Union, and for those nationals of a departing State who wish to retain their status as citizens of the Union". ${ }^{33}$ Similar to both these initiatives, the last initiative "Permanent European Union Citizenship" invites the Commission to assure all EU citizens that, once attained, the fundamental status of EU citizenship is permanent and their rights acquired. ${ }^{84}$

All three initiatives aim(ed) in essence at the adoption of an act of the Union which would enable EU citizens whose countries withdraw from the Union to retain their rights and status of EU citizen. In all three cases, the Commission responded in its registration decisions that it cannot propose an act of the Union aiming at granting the citizenship of the Union to persons who do not hold the nationality of a Member State. However, it accepted registration of the initiatives based on the understanding that they aim at ensuring that following the withdrawal of a Member State its citizens continue to benefit from similar rights compared to EU citizens. ${ }^{85}$ This means that although the subject matter of all three initiatives, as initially submitted by the organisers falls outside the powers of the Commission under the current Treaties, the Commission "re-qualified" their subject matter in a way that would allow acceptance for registration and collection of signatures. Requalification seems to go a step further than partial registration, since the Commission does not merely "clear" an initiative from its inadmissible elements, but it adjusts the subject in a way that could fall within its competences.

\section{IV.2 Shortcomings at the Post-Registration Stage}

This openness and cooperative spirit demonstrates a clear change of the Commission's practice and enables a more effective use of the instrument. However, the Commission has not so far ensured in cases of such "re-qualification" of content or in cases of partial registration that the information on an initiative

\footnotetext{
83 Available at <http://ec.europa.eu/citizens-initiative/public/initiatives/obsolete/details/ 2017/000005>.

84 Available at <http://ec.europa.eu/citizens-initiative/public/initiatives/open/details/ 2018/0000o3>.

85 See Commission Decision C(2017) 2001 of 22 March 2017 on the proposed citizens' initiative entitled "EU Citizenship for Europeans: United in Diversity in Spite of jus soli and jus sanguinis"; Commission Decision C(2017) 2002 of 22 March 2017 on the proposed citizens' initiative entitled "Retaining European Citizenship" and Commission Decision C(2018) 4557 of 18 July 2018 on the proposed citizens' initiative entitled "Permanent European Union Citizenship".
} 
made available to potential signatories and the public corresponds to the exact scope of the registration by the Commission.

The Commission made an attempt to guide organisers towards gathering signatures on the basis of the "requalified" content of the initiative. More specifically, in its positive decision to register the initiative "EU Citizenship for Europeans" the Commission indicated that "statements of support may be collected, based on the understanding that it aims at a proposal for a legal act of the Union that would ensure that, following the withdrawal of a Member State from the EU the citizens of that country can continue to benefit from similar rights to those which they enjoyed whilst that country was a Member State". ${ }^{86}$ However, the Commission did not use an equivalent caveat when accepting registration of the similar initiatives "Retaining European Citizenship" and "Permanent European Union Citizenship". This means that the registration of these two initiatives was unconditional and only in the recitals of the registration decisions the Commission mentioned this clarification of scope, although the need for a conditional registration is evident for these initiatives as well.

Furthermore, in all cases, the title and main aims of the initiatives, as displayed in the official Commission register and on the webpages where electronic signatures could/can be gathered, have not been adjusted to the Commission's "requalification" and feature(d) the initial inadmissible aim to decouple EU citizenship from nationality. As aforementioned, the webpage of the official register contains a disclaimer that the content of the page of the register dedicated to each initiative is the sole responsibility of the organisers of the initiatives. However, this approach leads to the result that the official register does not provide a clear image of the admissible content of initiatives.

Given this problematic situation, it is welcome, as mentioned above, that the new Regulation provides that, when partial registration takes place, the organisers shall ensure that potential signatories are informed of the scope of the registration and of the fact that statements of support are collected only in relation to the scope of the registration of the initiative. ${ }^{87}$ The obligation of organisers to accurately inform potential signatories should also apply, when the Commission "requalifies" an initiative, so as to shape it in a way that falls within its powers.

Apart from the organisers, the Commission should also ensure that all information appearing on its official register corresponds to the exact scope

$86 \quad$ See Commission Decision C(2017) 2001.

87 See recital 16 and Art. 6(5), lit. b), of Proposal for a Regulation сом(2017) 482 final, cit. 
of the registered initiative in accordance with the principle of good administration. As outlined above, ${ }^{88}$ this principle requires that the Commission provides adequate information and assistance to those involved in an administrative procedure. The different stages of a European citizens' initiative constitute altogether an administrative procedure, which ends with a Communication of the Commission in case of collection of the necessary number of signatures. ${ }^{89}$ It is true that the collection of signatures takes place without the Commission's intervention. However, the Commission should ensure that this collection is carried out in a transparent way and on the basis of accurate information. Otherwise, even the mere validity of signatures which were collected on the basis of inaccurate or wrong information can be called into question.

None of the Brexit-related initiatives managed to gather sufficient popular support in any Member State in order to reach the required one million signatures and be able to request from the Commission a possible follow-up action in line with their aims. ${ }^{90}$ They gained certain popularity in essence only in the UK and did not manage to create a transnational movement, which constitutes the added value of the ECI. ${ }^{91}$ Different reasons can be evoked in order to justify this failure, such as the limited network of the organisers, the fragmentation of signatures among similar initiatives or even the lack of interest of other EU citizens to mobilise for the sake of securing the rights of UK nationals. An important reason, connected with the subject matter of this contribution, could also be the non-adjustment of the titles and main objectives of the registered Brexit-related initiatives so as to be in line with the current Treaties. It is possible that the discrepancy between the current Treaties, which make EU citizenship conditional upon holding the nationality of a Member State, and the initiatives' objectives, which aim at decoupling EU citizenship from the nationality of a Member State, have caused loss of credibility of these initiatives.

In order to restore trust in the instrument and to present to the general public a realistic picture of the potential of an initiative, the need for reinforced mechanisms of cooperation among the Commission and the initiatives' organisers are critical.

88 See section I.

89 One of Us v. Commission, cit., para. 76 .

9o See the archived initiatives with insufficient support at http://ec.europa.eu/citizensinitiative/public/initiatives/obsolete/conditions_not_fulfilled.

91 On the strengthening of trans-European society as an added value element of the ECI, see Salm, C. (2018). The added value of the ECI, cit., p. 14. 
The instrument of the European citizens' initiative, as a tool of participatory democracy and EU citizenship, has the potential to reinforce the legitimacy of the political agenda and strengthen the active participation of EU citizens. The European Commission had been criticised for depriving the European citizens' initiative of its effectiveness due to its own institutional practice, particularly regarding the application of a strict admissibility test and the lack of adequate guidance to organisers. The Commission's practice following the judgment in case "Minority SafePack" shows that, from this point onwards, the Commission identifies the elements of the initiative on the basis of which it could make a proposal for an act of the Union and accepts registration for these parts. This adaptation of the Commission's practice is welcome and indeed enables the registration of more initiatives, while respecting the principle of conferral of Union powers. Partial registration also better takes into account the principle of legitimate expectations, since the registered initiative is cleared from its inadmissible parts and therefore both the organisers and potential signatories have this way an accurate picture of what they can achieve through their initiative.

The effective use of the instrument of citizens' initiatives depends also on a clear understanding of citizens as to its material scope of application. The judgment in case "sTOP TTIP" has contributed to enhancing legal clarity in this respect. However, the Commission, through its reasoning when accepting or rejecting initiatives, can further reinforce legal certainty, by explaining clearly to citizens what types of acts may fall within the material scope of an initiative. As the analysis of the admissibility of the initiative "British friends-stay with us in EU", which aimed at creating a discussion platform for Brexit, has shown, it remains unclear whether material acts could be the (principal) object of an initiative.

Brexit-related initiatives aiming at securing the rights of UK citizens have benefitted from the Commission's more open approach when assessing the admissibility of initiatives. When treating these initiatives, the Commission went even a step further than partial registration and showed a more proactive stance: it did not merely "clear" an initiative from its inadmissible elements, but it adjusted, i.e. requalified, the subject in a way that could fall within its competences.

However, the problem in the concrete implementation of this new approach is that the content of the initiative which was registered in the official Commission register (public website) was not adjusted to the Commission's decision, which had only accepted part of the initiative or which "requalified" the object, 
but continued to include the inadmissible parts. This could have the negative effect of creating false expectations for the signatories of the initiative, who will sign the initiative on the basis of the content featured on the website without looking concretely into the Commission decision of registration.

The impact of this instrument in the context of the Brexit negotiations can be assessed as limited. None of the Brexit-related initiatives have managed to gather sufficient popular support in order to reach the required one million signatures and be able to request from the Commission a possible follow-up action in line with their aims. A possible reason for this outcome could be the lack of credibility of these initiatives, whose titles and main objectives, as presented throughout the signature collection process, were at odds with the current Treaties as regards the relationship between EU citizenship and nationality of a Member State. The Commission should therefore guide the future organisers of an initiative as to how to adjust its title and content in accordance with the registration decision. Such obligations of assistance and cooperation derive from the principle of good administration understood in a broad sense through the lens of good governance. The evolution of the Commission's role from a mere respondent to a facilitator or even supporter of citizens' initiatives could potentially enhance the institutional role of this instrument. The initiation of six Brexit-related initiatives clearly demonstrates that, in a pressing situation for citizens' rights, the European citizens' initiative constitutes an important tool for EU citizens to raise their voices together. It remains to be seen whether these voices will gain greater force in the future. 